\title{
Poetyckie reakcje na porwanie Stanisława Augusta Poniatowskiego
}

Jacek Wójcicki 


\section{JACEK WÓJCICKI}

\section{Poetyckie reakcje na porwanie Stanisława Augusta Poniatowskiego}

U prowadzenie króla wieczorem 3 listopada 1771 roku - ów „,niesłychany przypadek" grzebiący sprawę konfederacji barskiej w opinii labilnych dotychczas potęg europejskich - ożywiło najróżniejsze formy publicystyki i literatury. Zamach na osobę monarchy zmuszał do jednoznacznej, jak najszybszej reakcji. Groźne Periculum in mora! wisiało zarówno nad stronnikami tronu, którym postępek Kuźmy-Kosińskiego dawał niezwykłą okazję wyrażenia i podkreślenia włąsnego zaangażowania, jak i nad zwolennikami konfederacji, dla których milczenie mogło oznaczać zgodę na argumentację szumnej propagandy oficjalnej. $Z$ urzędu zabierali głos biskupi w listach pasterskich i kaznodzieje na ambonach różnych wyznań; z urzędu niemal rymowali dworscy poeci i wierszokleci - nie brakowało jednak i spontanicznych ( $w$ sensie nieurzędowej gorliwości, nie zaś, rzecz jasna, szczerości) wyrazów oddania królowi. Ze strony przeciwnej - jako że pomysł porwania czy wręcz zabicia króla nie był powszechnie akceptowany przez konfederację - oficjalnych głosów uznania dla porywaczy nie publikowano, pojawiały się natomiast polemiki z tekstami regalistów, gdzie nie tyle podtrzymywano sens królobójstwa, co zbijano przesadne argumenty przeciw konfederacji i temperowano zachwyty pochlebców Poniatowskiego. Publicystyczne i literackie produkcje obydwu obozów kursowały jako druki ulotne, wędrowały poprzez kolejne kopie rękopiśmienne, a tam mogły natrafiać - z rzad ka - na teksty „obojętników”, nieliczne wprawdzie, ale - jak wolno sądzić - oddające zdanie większości spoleczeństwa szlacheckiego, unikającego zaangażowania się po którejkolwiek stronie męczącego i beznadziejnego konfliktu.

W porównaniu z innymi okresami literatury barskiej, prześledzenie wierszowanych polskojęzycznych ech 3 listopada (bo do takich ogranicza się zakres niniejszego artykułu) jest znacznie ułatwione za sprawą samych zainteresowanych. Oczywiście liczne silvae rerum nieraz przynoszą zwarte bloki tekstów „porwaniowych", przy czym często powtarza się polemiczny 
ciąg utworów: Do narodu i potomności... A.K. Kossakowskiego, anonima Od narodu do poety... (Respons na wiersze J.P. Kossakowskiego) oraz Wieśniak do poety dziennego A. Naruszewicza. Jednak prócz prywatnych i przypadkowych, rozsianych po sylwach, kolekcji utworów dotarły do nas dwa pokaźne (chociaż stronnicze, bo tylko prokrólewskie) zestawy mające charakter bardziej oficjalny.

Pierwszy zbiór to monograficzny niemal zeszyt "Zabaw Przyjemnych i Pożytecznych" (1771 t. 4, cz. 2), mający udokumentować prawomyślność literatów dworskich, lecz przede wszystkim ugruntować w oświeceńszych kręgach oficjalny ogląd $i$ interpretację wydarzeń feralnej nocy. Teksty „porwaniowe" przeważają w numerze, obejmują zaś nie tylko utwory oryginalne. Autorzy współcześni ( $w$ poniższym spisie wymienieni z nazwiska na podstawie spisu treści czasopisma i bibliografii) dostarczyli następujących dzieł wierszowanych (paginacja według pierwszej edycji "Zabaw"):

Zab. 1. Adam Naruszewicz, Oda do Ojczyzny z okazyi nies/ychanego przypadku Jego Królewskiej Mości (s. 321-334);

Zab. 2. Ignacy Nagurczewski, Do Najjaśniejszego Pana młódź Korpusu Kadetów (s. 335-338);

Zab. 3. Wojciech Jakubowski, Wiersz z okazyi okropnego przypadku dnia 3 Novembris spraktykowanego (s. 339-341);

Zab. 4. Antoni Korwin Kossakowski, Do narodu i potomności o okropnym przypadku przez Jego Królewską Mość... doświadczonym (s. 342-360);

Zab. 5. Kazimierz Nestor Sapieha, Wiersz na dzień doroczny koronacyi [25 XI] Najjaśniejszego Stanislawa Augusta od Korpusu Kadetów ofiarowany (s. 361-366);

Zab. 6. Adam Naruszewicz, Do Króla Jegomości w dzień doroczny szczęśliwej jego koronacyi oda (s. 367-378);

Zab. 7. Józef Epifani Minasowicz, W tejże materyi (s. 379-382);

Zab. 8. Grzegorz Piramowicz, W tejże materyi. Oda I. Ojczyzna do obywatelów (s. 383-388); Oda /l (s. 389-398).

W kręgu wydarzeń na Senatorskiej pozostawały też zamieszczone dalej tłumaczenia z Horacego: oparta na motywie "nawy Republiki" alegoryczna pieśń 1140 navis, referent in mare te novi w tłumaczeniu Michała Kończy (s. 399-401), jakże aktualna II 13 I/le et nefasto te posuit die, w thumaczeniu Józefa Koblańskiego zatytułowana Na drzewo, którego upadkiem malo nie byl zabity (s. 406-409) i II 2 Nullus argento color est avaris przełożona przez tegoż Koblańskiego, a zawierająca obecne w propagandzie prostanisławowskiej zdania o wyższości królów cnotliwych nad chciwymi dostatków (s. 410-411). Jedynie drobne fragmenty Epistulae ex Ponto I 1 Owidiusza w tlumaczeniu Kończy (s.402-405) i horgcjańskie zaproszenie do Tyburu c. II 
6 Septimi, Gadis aditure mecum w wersji Koblańskiego (s. 412-414) można uznać za apolityczne. Oczywiście w późniejszych tomach „Zabaw” również odnaleźć można inne utwory genetycznie związane $z$,okropnym przypadkiem" króla, lecz ich treść oddala się już od wyraźnej okolicznościowości ku abstrakcyjnym roztrząsaniom kwestii mechanizmów historii, etyki rządzenia i cnót władców. Tak oto w tomie 5 cz. 1 z 1772 Naruszewicz ogłasza Wiersz radosny, który Grecy z Łacinnikami dytyrambem zowią, z okazyi zupelnego ozdrowienia Jego Królewskiej Mości (s. 3-22), w cz. 2 tegoż tomu odę Do Wielkiego Księstwa Litewskiego... z okazyi uroczystej delegacyi z... powinszowaniem ocalonego... życia i zdrowia J.K.M. (s. 299-308), a w cz. 2 tomu 6 utwór Na dzień ocalenia życia i zdrowia Jego Królewskiej Mości pieśń doroczna (s. 277-285). W następnym, 1773 roku zaś czasopismo zareagowało na mowę króla w obronie zamachowców, wygłoszoną 2 sierpnia, trzema utworami wierszem, z których najwyżej wypada ocenić znów Odę do Sprawiedliwości... Naruszewicza (t. 8 cz. 1 s. 99-111).

Zbiór drugi jest znacznie obszerniejszy i w przeciwieństwie do zeszytu „Zabaw" przeznaczony był dla wąskiego kręgu odbiorców. Mowa o przechowywanym w Bibliotece Czartoryskich w Krakowie rękopisie 781, będącym w istocie 426-stronicowym kodeksem rękopiśmiennych i drukowanych kazań, listów pasterskich, pism prozą i utworów wierszowanych dotyczących porwania króla (paginacja nie obejmuje druków). Umieszczone w zbiorze dokumenty wskazują, że kompilacji dokonać mógł ktoś bardzo zbliżony do kancelarii królewskiej, niektóre bowiem utwory mają charakter bezpośrednich przesyłek na ręce Stanisława Augusta. Oprócz tekstów eklezjastycznych i prozatorskich opisów porwania (jak Parens patriae Stanislaus Augustus... a parricida ereptus... J.D.A. Janockiego czy przypisywany S. Konarskiemu Providentiae divinae evidens argumentum... Stanisława Bohusza Siestrzeńczewicza) w tomie zamieszczono druki i odpisy utworów poetyckich (lub do tego miana beztrosko aspirujących) w języku polskim, francuskim, niemieckim i łacińskim. Muzę polską reprezentują ( $w$ nawiasach utwory znane z „Zabaw Przyjemnych i Pożytecznych“):

R. 1. Mateusz Czarnek, inc. „Królu! Twoje do swoich cudowne przybycie..." (rps, 108 w., s. 347-350);

R. 2. Do narodu po nieszczęśliwym przypadku Najjaśniejszego Króla, inc. "Co widzę? gdzie zostaję? co się teraz dzieje? (rps, 248 w., s. 355-362);

(R. 3.) K.N. Sapieha, Wiersz na dzień doroczny koronacyi... (rps, s. 363-366, = Zab. 5);

(R. 4.) J.E. Minasowicz, Najjaśniejszemu Najpotężniejszemu Stanislawowi Augustowi... na dniu dorocznym szczęśliwej koronacyi... (druk, 4 s. nlb, po s. 366 , = Zab. 7); 
R. 5. Wiersz Najjaśniejszemu Panu w dzień podziękowania Bogu, które Dwór J.K.Mci czynil za cudowne zachowanie życia i zdrowia... pana swego ofiarowany 24 [rz.] listopada 1771 [rz.], inc. "Racz przyjąć, królu, radosne okazy..." (druk, $4 \mathrm{~s}$. nlb, dalej po s. 366);

(R. 6.) A. Naruszewicz, Do Króla Jegomości... (druk, 8 s. nlb, dalej po s. $366,=$ Zab. 6);

(R. 7.) A. Naruszewicz, Oda do Ojczyczny... (druk, VIII s., dalej po s. $366,=$ Zab. 1);

R. 8. Oda do Najjaśniejszego Pana, inc. „O, jakby zjednać Muzę tak miłą, tak dzielną..." (rps, 56 w., s. 367-370);

R. 9. Oda z okazyi ocalenia drogiego życia Najjaśniejszego Króla Jegomości Stanislawa Augusta, inc. „Okropnym Faetona król Cygnus przypadkiem..." (rps, 80 w., s. 371-375);

R. 10. Do Najjaśniejszego Pana dobry obywatel, inc. "Niech zazdrość, zdrada, jakie chce bierze przemiany..." (rps, 108 w., s. 385-389);

R. 11. Tekst z przyczyny przypadku przez Jego Królewską Mość doświadczonego, inc. „Uzbrój się orężem, Kto się zowiesz mężem..." (rps, 35 w., s. 393);

(R. 12.)A. Naruszewicz, Wiersz radosny ... (druk, po s. 393, = "ZPP" 1772 t. 5 cz. 1 s. 3-22);

(R. 13.)G. Piramowicz, Wiersz w dzień dorocznej pamiątki koronacyi... - Oda I. Ojczyzna do obywatelów - Oda II (= Zab. 8) - III [w jęz. franc., inc. "Du Toutpuissant la main propice Plus d'un fois combla le precipice"] (druk, dalej po s. 393);

R. 14. A. Naruszewicz, O pożytku z nauk... (druk, = "ZPP" 1772 t. 5 cz. 1 s. 169-190, dalej po s. 393);

R. 15. A. Naruszewicz, Na dzień siedemnasty stycznia urodzeniem Jego Królewskiej Mości znakomity oda (druk, dalej po s. 393);

R. 16. Marcin Eysymont, Palemon. Ekloga - Epigrammata ad nobilem iuventutem: Nova divinior metamorphosis; In vocem sicarii... primam...; Sicarium rex exarmat...; Augustus Octavius Cinnae coniuratisque... [każdy z epigramatów po łacinie i po polsku] (druk, dalej po s. 393);

R. 17. Wiersz polski i laciński Najjaśniejszemu Panu w dzień pamiątki jego urodzenia 17 [rz.] stycznia roku 1772 [rz.] ofiarowany od wiernego poddanego i slugi S.P., inc. „Dniu jaśniejszy nad inne i jeden z dni wiela..." (druk, 30 w., tamże tłumaczenie łacińskie dystychem elegijnym, dalej po s. 393). 
Wierszom R. 16 i R. 17 towarzyszyły wersje lacińskie; warto odnotować w tym miejscu, że Ode do Ojczyzny Naruszewicza tłumaczył później na ten język Franciszek Dionizy Kniaźnin (el. Il 1 Ad Patriam w zbiorze Carmina, Warszawa 1781) ${ }^{1}$. Autorem zaś niemieckiego przekładu ody Naruszewicza, zamieszczonego w omawianym kodeksie (gdański druk szwabachą, $16 \mathrm{~s}$. nlb, po s. 258) jest Johann Gottfried Gusovius (Ode an das Vaterland bey der Erretung Ihro Königl. Majestät von Pohlen... aus einer nahen Lebensgefahr...).

Teksty w języku niemieckim umieszczone w rękopisie Czart. 781 mają dwojaki charakter. Prócz przekładu Gusoviusa gatunki ściśle literackie reprezentuje anonimowy druk gdański Der Dritte November, eine Ode (Danzig 1771, 8 s. nlb, po s. 258), rękopis Gedancken über der Sr. Königl. Maiest. von Pohlen Stanislao Augusto... Krafft Gottes... Schutze Neu aufgegangenen Sonne des Lebens... entworffen von... Valentin Friedrich Müller, Senator zu Namislau in Schlesien (s. 260-269), poemat F.A. Albrechta Der Raub des Koenigs Seines Herzen. In Vier Gesaengen... (rps, s. 273-301) czy wiersz ku czci króla w liście A.M. Klattego (s. 305-306). Takie zaś utwory, jak Hymnus auf die Erretung des Königes. Von einem Curländer (druk szwabachą, 8 s. nlb, po s. 258) czy zachowany tu w kilku drukach szwabachą oraz antykwą Ein Gesang am Danckfeste, wegen der Errettung des Koenigs (na nutę słynnego chorału Lutra Ein' feste Burg ist unser Gott) stanowią elementy liturgii dziękczynnych, odprawianych w świątyniach protestanckich Śląska czy Pomorza. Spośród zdecydowanie świeckich tekstów francuskich ofiarowanych królowi można natomiast wymienić, jako przykład konwencjonalnej literackości, poemat Françoisa Nicolasa Dusserta, redaktora "Journal Polonais", Le Triomphe de la Providence... (rps - autograf? - s. 107-112, druk s. 115-118) czy anonimową machinę w czterech pieśniach La delivrance heureuse de Sa Majesté le Roy de Pologne (rps na s. 175-204).

Zawarte w obu zbiorach polskie utwory wierszowane pozwalają dostrzec nie tylko nieuniknione i spodziewane podobieństwo tez propagandowych, stylu argumentacji czy rozwiązań formalnych, lecz także znaczne nieraz różnice indywidualne $\mathrm{w}$ podejściu do tematu, próby ożywienia zastanej konwencji literackiej i wcale głęboką niekiedy refleksję-dalekie w sumie od naszego powierzchownego wyobrażenia o płaskiej robocie dworskich panegirystów. Za sztandarowego przedstawiciela tej gildii uchodzi Narusze-

\footnotetext{
'Badaczka twórczości Kniaźnina podkreśla wysoki poziom przekładu, samodzielność zmian idących ku latynizacji elegii, ale i dążenie do zachowania w całości toku myśli Naruszewicza, nawet metodą wlączania fragmentów z innych wierszy (rozwinięcie apokryficznych słów Zygmunta Starego o ,, bezpiecznym śnie na łonie rodaków" z ody Na Pokój Marmurowy...); zob. Ewa Jolanta Glębicka, Lacińska poezja Franciszka Dionizego Kniaźnina. Wroclaw 1993, s. 172-176.
} 
wicz, i jest on w rzeczy samej autorem większości wymienionych utworów. Nie ma jednak i u niego jednostajności, poszczególne wiersze związane z porwaniem króla mają wyraźnie różne oblicza.

Waga tematu wymuszała od razu podniosły, solenny styl wypowiedzi. Twórcy w większości sięgnęli po formę ody (związaną ze stylem wysokim i nie obwarowaną ścisłymi rygorami formalnymi), zaznaczając to już w tytule (Naruszewicz, Piramowicz, anonimowe ody R. 8 i R. 9) bądź też nie (Czarnek, anonim. R. 2, R. 10, R. 17). Blisko ody sytuuje się modlitwa (Jakubowski). Gatunek pośredni między odą i sielanką reprezentuje Kossakowski (refren „Gęśli moja..." powracający kilkakrotnie w narracji w różnych wariantach), zaś typową sielanką alegoryczno-panegiryczną jest Palemon Eysymonta. Naruszewicz sięgnął też po dytyramb, wyjaśniając w obszernym przypisie zasady nim rządzące (czy raczej właśnie ich brak).

Podniosłej wypowiedzi odpowiada poważny adresat - jest nim najczęściej król, ale i Bóg, Ojczyzna, naród, potomność; jeśli adresatami są współcześni, przemawia sama Ojczyzna lub aniołowie, bądź też odbiorcą jest elitarna grupa (duchowieństwo w Pieśni dorocznej... Naruszewicza, "ZPP" 1772 t. 6 cz. 2). Jeśli adresat nie został wyraźnie nazwany, odpowiednio wzniosły jest przedmiot relacji, jak np. rozpaczający Apollo w Il odzie Piramowicza. Trzeba też dodać, że adresat wypowiedzi może zmieniać się kilkakrotnie na przestrzeni wiersza, panegiryk może być miejscami modlitwą.

Wybór gatunku kierował doborem środków stylizacyjnych. W odach pojawiają się nie tylko pojedyncze, zleksykalizowane akcenty mitologiczne, jak ,,jędza krwawa z Tenaru”, ,,Kloto" (Zab. 1) i ,,Dedal" (Zab. 6) u Naruszewicza czy "Febus" i "Erynnis" u Kossakowskiego (Zab. 4), lecz przede wszystkim złożone sceny i obrazy stanowiące fundament konstrukcji czy wywodu myślowego. Tak oto w wierszu K.N. Sapiehy (Zab. 5) Stanisław August jako twórca Szkoły Rycerskiej został nazwany w obszernej frazie "powtórnym Deukalionem" przemieniającym "grube kamienie" w nowy naród, poczynania konfederatów skwitowano zaś:

Jak po starych olbrzymach niegdyś od Jowisza,

Nie wątpim, że nastąpi po tej burzy cisza ${ }^{2}$

a wówczas "Janus swój kościół zatrzaśnie”. Rozbudowaną, kunsztowną scenę rozpaczy Apolla (z powodu porwania króla), za sprawą Muz przemienionej w radosny zgiełk instrumentów i głosów (na cześć ocalenia monarchy) jest cała II oda Piramowicza (Zab. 8). Jednym z motywów utworu

2 Interesujące, że właśnie o motyw gigantomachii wzbogacił swój przekład - czy pod wplywem tego wiersza? - ody Naruszéwicza Kniaźninj zob. J. Głębicka, op. cit., s. 174. 
Czarnka (R. 1) jest modlitwa do Najwyższego o zmiłowanie, oparta na myśli: los Polaków jest gorszy niż Troi, bo Priam zginął wraz z jej mieszkańcami, tymczasem

My utracili króla, i jeszcze żyjemy!

Albo niech się powróci, albo niech giniemy!

Oda z okazyi ocalenia drogiego życia... (R. 9) rozpoczyna się wspomnieniem przykładów skrajnego przywiązania: Cygnusa do Faetona i Amfinomei do syna, Jazona - zestawionych następnie z uczuciem narodu do poszkodowanego króla. Oczywista jest również rola sztafażu bukolicznego u Eysymonta oraz wizji Parnasu w dytyrambie Naruszewicza.

$\mathrm{Na}$ uwagę zasługują rozwinięte porównania homeryckie, pozwalające nawet założyć zależność pomiędzy kilkoma utworami. Względnie niepowtarzalne obrazy to np. u Kossakowskiego rejwach na wieść o porwaniu króla zestawiony z wizją miotającego się po jaskini lwa (Zab. 4), u Naruszewicza (Zab. 1) porywaczy porównano do skradającego się po owce wilka, a w Dytyrambie sporo miejsca zajmują obrazy ożywianego przez rosę kwiatu i statku wśród burzy docierającego do portu. Jednak aż trzech autorów sięgnęło po ten sam epicki obraz: Czarnek (R. 1), Kossakowski (Zab. 4) i Naruszewicz w dytyrambie porównują pozbawiony króla bezradny naród do roju pszczól, którym zabrano władcę (Czarnek), „macierze” (Kossakowski), „wodza złotego" (Naruszewicz). Wolno przypuszczać, że ten ostatni posłużył się nie publikowanym tekstem Czarnka, bowiem w Dytyrambie pojawia się i motyw wszczęcia radosnego zgiełku,

Lecz nie tym wrzaskiem strasznym, szalonym, Kiedy sierdzisty Mars w ustalonym [= stalowym]

Sardaku walcząc $z$ piekielnym bratem

W Etnie pławionym macha bułatem. (w. 247-250)

U Czarnka jest także Mars "serdakiem żelaznym odziany".

Na pograniczu stylizacji klasycznej i biblijnej stoi użyty przez Naruszewicza (Zab. 6) obraz ,"płochego jelonka w myśliwczych obierzach", kierujący myśl czytelnika ku psalmicznym parafrazom Jana Kochanowskiego. Wcześniej do Kochanowskiego Naruszewicz nawiązał w Odzie do Ojczyzny... (Zab. 1, w. 129-140), kształtując opis uratowania króla na wzór psalmu 91 (Kto się w opieke poda Panu swemu) jako łańcuch wyliczeń. Uczynił tam również aluzję (w. 75-76) do początku pieśni I 22 (Rozumie mój, próżno sį̨ masz frasować). Podobnie długi ciąg literackich odniesień znajdujemy u Czarnka: w. 21-26 to parafraza Kochanowskiego Epitalamium z Katulla (w. 17-22, apostrofa do Hesperusa), zaś w. 27 28 to parafraza leksyki Trenu / (w. 1-4). 
Wzorzec konstrukcyjny ody przynosi również obrazy nie stanowiące aluzji klasycznych w ścisłym sensie, lecz ukształtowane na podobieństwo uniesień wieszczów greckich i rzymskich: przemowy „piekielnej jędzy" czy „wyniosłości" w wierszu Do narodu... (R. 2) lub-już w duchu chrześcijańskim - oracja anioła-stróża Zygmunta III (który ochronił króla przed ciosem Piekarskiego) w Pieśni dorocznej... Naruszewicza. Do rodzimej tradycji literackiej, ale związanej z językiem Rzymian, nawiązuje Eysymont w polsko-łacińskich Epigramatach: budowane na wzór Macieja Sarbiewskiego erudycyjne koncepty, opisujące „cudowną przemianę" porywacza w obrońcę króla pod wpływem łagodności i czaru monarchy (ale przede wszystkim za sprawą Boskiej Opatrzności), układają się zarazem w cykl podobny do barokowych wierszy typu "Na one słowa..." z Biblii, czy wręcz - nie jest to chyba skojarzenie zbyt dalekie - opisów Męki Pańskiej w kolejnych stacjach.

Stylizacja modlitewna pozwala na użycie obrazów biblijnych. W wierszu Jakubowskiego (Zab. 3) takimi odwołaniami są postaci Baltazara (w. 13-14) i Dawida (w. 27), u Kossakowskiego (Zab. 4) mamy paralelę starotestamentową: opór ludu izraelskiego przeciw Mojżeszowi (w. 127).

Na tle utworów w szerokim sensie ",klasycznych" wyjątkowe miejsce zajmuje Tekst z przyczyny przypadku... (R. 11), gdyż jest to rzadki przykład wykorzystania przez propagandę królewską wzorca popularnych wśród konfederatów pieśni-pobudek bojowych. Utwór w zwięzłej formie porusza wszystkie zgoła aspekty obrazu wydarzeń współczesnych kreowanego w Warszawie.

Podstawą tego obrazu, zarówno w publicystyce i kaznodziejstwie, jak i w przeważającej części wierszy, jest sankcja religijna dla władzy królewskiej. Król jest Bożym pomazańcem, a więc zamach na niego to świętokradztwo. Bóg nie dopuszcza jednak, by wybrańca skrzywdzono: Opatrzność czuwa nad władca, a cudowne ocalenie to jawny znak wybraństwa, zgoła powtórna koronacja. Ale i sam król ma udział w niezwykłym zdarzeniu: jego cnoty wynoszą go ponad koronowanych poprzedników, a wielce ważyło też ofiarowanie swoich cierpień dla dobra ojczyzny. Palec Boży objawił się również w metamorfozie Kuźmy-Kosińskiego, skoro ten niedoszły - ale gotów na wszystko - morderca stał się obrońcą i przewodnikiem rannego monarchy.

Na płaszczyźnie metafizycznej sprawa jest prosta i czytelna: Opatrzność czuwa, niech nikt nie waży się na podobny czyn; Minasowicz nie omieszkał przy okazji dopiec deistom i racjonalistom (Zab. 7, zwł. w 19-22). Jednak na poziomie czysto ziemskiej polityki nie ma jednoznacznego potępienia dla konfederatów. Wyraźnie oddziela się „garść złoczyńców” od reszty narodu, skłóconego, ale nie pozbawionego własnych racji. Szczególnie sprawiedliwy, w przeciwieństwie do miotającego obelgi Kossakowskiego, stara się być Naruszewicz (Zab. $1, w, 41,-44)$ : 
Broń tych swobód, broń przodków starożytnej wiary,

Te są najgruntowniejsze narodu filary;

Lecz czy na tym się wolność i wiara zasadza,

Że swe króle zbestwiona tłuszcza z życia zgładza? -

chociaż dalej stwierdza (Zab. 6, w. 49-50):

Samiśmy przygód naszych sprawcami ogniwa,

Że wszystko opak bierze zazdrość nieżyczliwa.

Niezależnie od tego, czy zamęt w kraju to wynik działań nadprzyrodzonych (jak intrygi upersonifikowanej Nienawiści i Zazdrości w wierszu R. 2 Do narodu... czy wręcz dopust Boży za grzechy w Odzie... R. 9), czy też nieusuwalnych, nie mających jawnej przyczyny, cech całego narodu z dawien dawna (o czym wspomina Naruszewicz w Zab. 6 czy "dobry obywatel" w wierszu R. 10) - żaden monarcha nie może już powtórzyć przypisywanych Zygmuntowi Staremu słów,

\section{Że na łonie Polaka król bezpieczen zaśnie}

(Kossakowski, Zab. 4, w. 30). Okrucieństwo, jakiego nie znają nawet „dzicy Huronowie" (Naruszewicz, Zab. 1), "Murzyn brudny" i "Afrykan srogi" (Piramowicz, oda II, Zab. 8), "Hyrkanowie" i "Sarmaci” (Eysymont, Palemon, R. 16), nierząd, brak sprawiedliwości - stawiają nas za pośmiewisko Europie i światu. Optymistyczna wizja Minasowicza, że inni zazdroszczą nam ,złotej swobody" (Zab. 7, w. 41-42), pozostaje wyjątkiem. Jednak nawet Sokratesa pokonala niesprawiedliwość (Naruszewicz, Zab. 6) - może nie jesteśmy inni niż świat? $W$ każdym razie żaden z królów nie podobał się Polakom, choć zmarłym stawia się pomniki (Naruszewicz, Zab. 6; „dobry obywatel", R. 10). Stąd apel do Stanisława Augusta: czynić swoje (Naruszewicz, Zab. 6), jedyną pociechę upatrując w przyszłej sławie (R. 10). Potomność jest od razu wzywana na arbitra i upominana, że hańba złoczyńców nie może spadać na cały naród (Kossakowski, Zab. 4).

Tak skomponowany, stronniczy obraz wydarzeń, z centralną postacią idealnego, lecz nie rozumianego $i$ atakowanego władcy, nie dopuszczał żadnej niemal dyskusji - przenikający go duch "świętego oburzenia" miał wywrzeć presję na sądy każdego pobożnego katolika. Niemniej wyraźne rozgraniczenie "warchołów" i prawomyślnego, chociaż otumanionego "narodu", dawało sympatykom konfederacji szansę uniknięcia konfliktu sumienia i mogło być odbierane jako zachęta do porzucenia obozu popierającego zbrodnie wobec monarchów. Do wyjątków należy wyzbyty metafizyki wywód Naruszewicza (Zab. 6) czy wyważona oda R. 9. Zazwyczaj po- 
chwały wobec króla wznoszą się na najwyższy poziom, usprawiedliwiony nie tyle autentycznym uniżeniem autorów, co wymogami stylu wysokiego i troską o wywarcie właściwego wrażenia na przeciętnym odbiorcy.

Nie związani regułami gatunku przeciwnicy ostro reagowali na zalew wierszowanego - różnej zresztą, nieraz sporej, wartości poetyckiej - prokrólewskiego panegiryzmu. Pojawiły się wprawdzie i glosy umiarkowane, jak np. Opisanie królewskiego przypadku z rpsu Ossolineum 572 s. 101-103 (obecnie we Lwowie). Wiersz ten operuje również metafizyką religijną i biblijnym motywem Jonasza, ale porwanie odczytuje jako ostrzeżenie od Boga, nie zaś ponowną koronację. Król - zdaniem autora - kazał porwać senatorów, a teraz sam został porwany; "czym zwykł kto grzeszyć, tym karany bywa" ( $w$. 27) - choć w żadnym razie ani lud, ani Pułaski nie stoi za terrorem. Jednak nie jest to tekst rozpowszechniony tak szeroko, jak inne „responsy" na utwory Naruszewicza i Kossakowskiego.

Oda do Ojczyzny Naruszewicza (Zab. 1) wywołała co najmniej dwa wierszowane "odpisy". Pelen antydysydenckich akcentów Żalosny i troskliwy odglos do Ojczyzny... (rps bibl. Czart. 830 IV s. 154-157) usprawiedliwia szlachtę, która jako jedyna przeciwstawia się płynącemu z góry, ze strony ,króla kalwina, lutra prymasa" i rozpustnych książąt, powszechnemu zepsuciu i marazmowi. Wiersz rozbija propagandowy majak ogólnego szczęścia pod rządami Stanisława Augusta, winiąc za jego szerzenie dworskich poetów z Naruszewiczem na czele. Katalog przewin króla i przytyki ad personam przechodzą pod koniec utworu w pobudkę dla prawdziwych synów z ust Ojczyzny (warto pamiętać o wyrażanych na początku utworu planach mocarstwowego odwetu na sąsiadach, o którym wyższe warstwy społeczne nawet nie mają odwagi pomyśleć). Co ciekawe, wiersz jednoznacznie negatywnie ocenia Kuźmę: tylko łotr jak on mógł dokonać czynu, którym brzydziłaby się szlachta - gdyż tak nędzną figurą jest król-Ciołek. Autor sprawnie operuje narracją i odpiera argumenty Naruszewicza, choć nie sięga jego poziomu literackiego. Drugi utwór polemiczny, Odpis na wiersze ojca Naruszewicza... (rps PTPN 399 k. 5-6 v.), to z kolei atak na jezuitów z pozycji „,pewnego dysydenta”. Autor cierpliwie, acz z pasją zbija tezy Naruszewicza przypominając, że porwanie było dzielem "mędrszych głów" i można się go było spodziewać już po ogłoszeniu bezkrólewia w październiku 1770 roku. Kuźma-Kosiński doczekał się tu pochwały. Zdecydowanie antymoskiewski polemista nie waha się wymienić litanii nazwisk sprzedawczyków (pełne cztery linijki, do rymu!), by ostrzec, że „,przyjdzie kryska na Matyska". Tekst jest boleśnie trzeźwy i w przeciwieństwie do poprzedniego unika akcentów dewocyjnych.

Znacznie wyższy poziom rzemiosła prezentuje polemika z wierszem Kossakowskiego - $\mathrm{i}$ to nie tyle anonimowa odpowiedź Od narodu do poety.... kontrapunktująca liste przymiotów króla wymienianiem przewin, by 


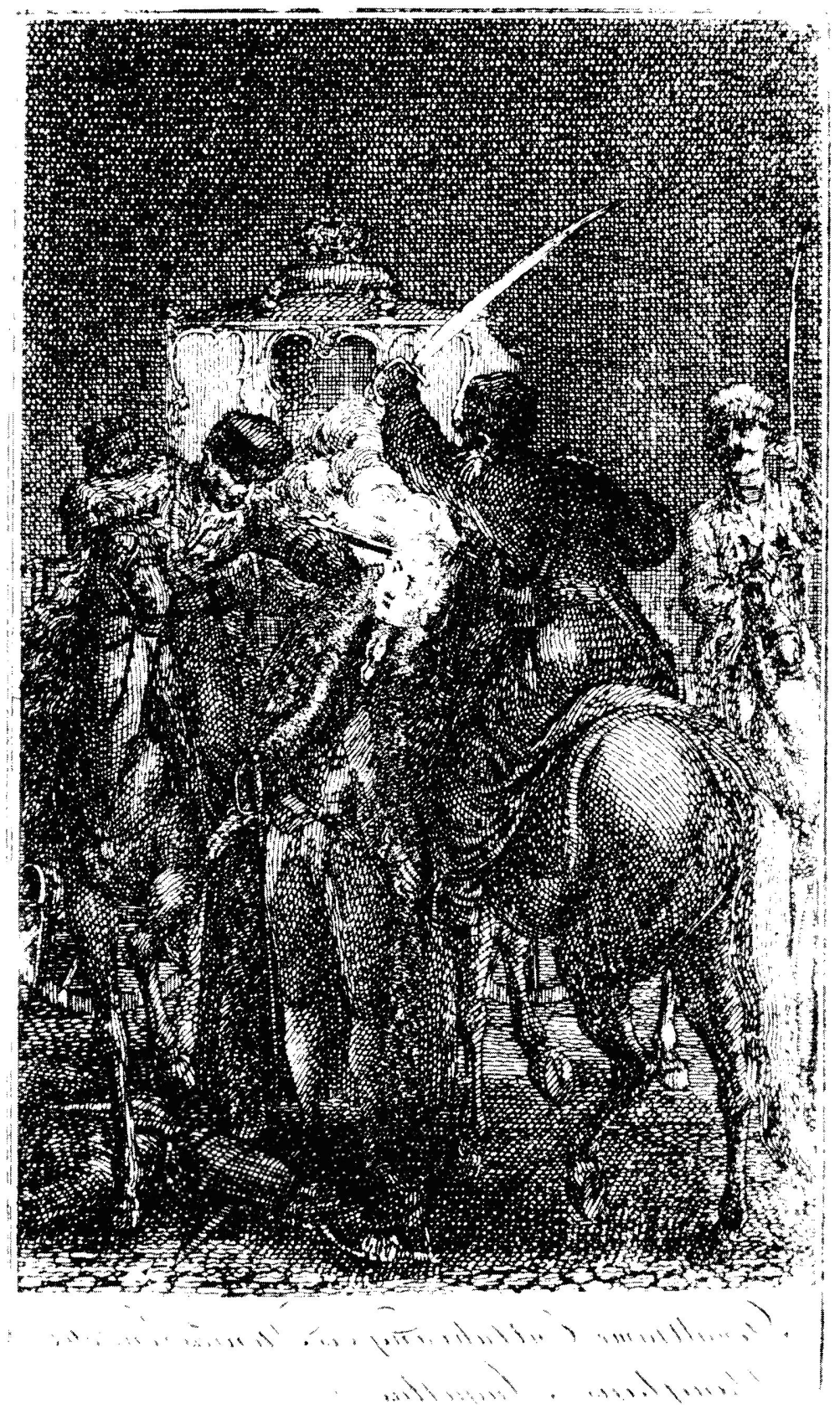

Rys. 6 Daniel Chodowiecki: Porwanie Stanisława Augusta Poniatowskiego $\mathrm{w}$ roku 1771. 1790 
dojść do wniosku ,jaki pan, taki kram", co replika Naruszewicza znana pod tytułem Wieśniak do poety dziennego. Tu późniejszy biskup smoleński według planu pieśni „poety dziennego" wskazuje na źródło nieszczęść tkwiące w samej szlachcie - bezrozumnej, naiwnej, oszukiwanej, a zarazem dumnej $\mathrm{i}$ pysznej bez powodu, gdyz urodzenie nie stanowi gwarancji doskonałości człowieka. Naruszewicz, autor skomplikowanych, wzniosłych ód, tu jakby traci cierpliwość i wyjaśnia wszystko bez ogródek, już w prostszym i dosadniejszym stylu. Argumenty religijne $w$ ogóle nie padają - do kolegi-literata (choć oponenta) trafić moga raczej wywody racjonalne. Podobnie przecież przemawiał do adresata na pewnym poziomie - $w$ wierszu Lio króla jegomości... - Zab. 6.

Odosobnionym utworem $z$ grupy antykrólewskich reakcji na dzień 3 listopada pozostaje satyryczny dialog Rozmowa Bartka z Grochowa z Maćkiem Hawrzynieckim... (dobry odpis w rpsie AGAD 248/300 s. 278-290). Sprawna stylizacja gwarowa, dosadny styl, pikantne plotki obyczajowe $\mathrm{i}$ ton krytyki społeczeństwa z pozycji "prostaków” kazały przypuszczać badaczom (za Ignacym Chrzanowskim), że i jego autorem mógł być Naruszewicz, czego jednak nie podtrzymuje się obecnie. Bartek z Maćkiem gwarzą coraz odważniej przy gorzałce, roztrząsając okoliczności porwania i ocalenia króla, lecz mimo wszystkich złośliwości dochodzą do wniosku, że byłoby źle, gdyby Stanisława Augusta miało zabraknąć.

Spośród poetów prokrólewskich najwyższą doskonałość osiągnął Naruszewicz, w kilku tekstach ujmując temat rozmaicie w zależności od spodziewanego odbiorcy, obranego wzorca gatunkowego (oda, dytyramb, wiersz polemiczny z akcentami parodii), a w związku z tym - od stopnia konwencjonalności utworów. Bardzo udane są również utwory Piramowicza i Czarnka, a spośród mniej znanych anonimów zwłaszcza ciekawa fabularnie oda R. 2, moderatorska R. 9 i wyjątkowo dojrzała, filozoficzna R. 10 Do Najjaśniejszego Pana dobry obywatel. Eysymont w swojej kolejnej sielance nie schodzi poniżej osiągniętego poziomu, bardzo klarowne są wiersze Jakubowskiego i Sapiehy. Oponenci zaś dają dowody raczej szczerego wzburzenia i trzeźwej myśli niż natchnienia, chociaż i oni - zwłaszcza w Rozmowie Bartka z Grochowa... - rymotwórczym przygotowaniem wystawiają sobie dobre świadectwo.

Obok stosunkowo łatwo dostępnych dzieł Naruszewicza i wierszy z "Zabaw Przyjemnych i Pożytecznych" część utworów znana jest z-niedoskonałych niekiedy - publikacji Ignacego Chrzanowskiego (Dzień 3 listopada roku 1771 w poezji wspólczesnej, w tegoż Z dziejów satyry polskiej XVIII wieku, Warszawa 1909 - Rozmowa Bartka..., Od narodu do poety..., Wiesniak do poety dziennego), Kazimierza Kolbuszewskiego (Poezja barska, Kraków 1928, BN I 108) i Janusza Maciejewskiego (Literatura barska, Wrocław 1976, BN I 108), Obecnie, ze świadomością, że temat nadal czeka 
na szczegółową analizę, a teksty na rzetelną edycję, warto przypomnieć kilka mniej znanych, zarówno prokrólewskich z rękopisu zestawionego być może dla samego Stanisława Augusta, jak i będących reakcją na natrętny głos muzy dworskiej.

1. Żałosny i troskliwy odgłos do Ojczyzny z okazyi niesłychanych zamachów na upadek wiary i wolności chytrze uknowanych przysądzeniem contra oda z przypadku JKM do Ojczyzny napisanego

Rps BCzart. 830 IV s. 154-157

Kto mnie odstapi, ten mnie zgubi.

Patrz na tyle zamachów, Ojczyzno strapiona,

Które ci uknowały syny z twego łona,

Chcąc pokazać dowody niby pelikana

W utrzymaniu tyrana za dobrego pana!

Pelikan rwie wnętrzności, lecz szczyrą prostotą,

Ci nie tylko wnętrzności - rwią serce z ochotą,

Pelikan rwie z miłości, ci w chytrej posturze

Czynią gwałt Kościołowi i własnej naturze.

Nieszczęście sądząc szczęściem, zgubę ocaleniem,

10 Na cnotę narzekają, całość użaleniem

Naganiaja, choć w większe okuwać kajdany

Wiarę, wolność, i syny w moskiewskie majdany

Oddać nielitościwie, którzy krew w ofiary

Chętnie swą poświęcili broniąc rzymskiej wiary;

15 Jęczą w więzach prawdziwi Ojczyzny synowie,

Broczą w krwi własnych braci w domach swych ziomkowie.

Czekają z utęschnieniem jarzma na swe karki,

Pragną przyjąć niewolą moskiewską na barki,

Przebóg, ach, co się dzieje? Kres upadku blisko,

20 Jakie obcym narodom jest urągowisko!

Straszny pałasz słabieje, męstwu nucąc vale,

Gospodarz, kmiotek, w domu rozpościera żale

Nad upadkiem Ojczyzny przez niesforne syny,

Próchnieje filar wiary, mocnią się kalwiny.

25 Senat już rozdwojony, rycerstwo zbłąkane, Duchowieństwo zepsute, prawa są stargane,

Król kalwin, luter prymas, książęta rozpustne,

Lecz z stanu szlacheckiego syny nie są gnusne,

Biorą się do oręża chcąc odnowić sławę, 
Polskę stąd rozprzestrzenić, odzyskać buławę, Inflanty z gardła wydrzeć, z moskiewskiej paszczęki, $\mathrm{Na}$ stolicy carowej impet wstrzymać ręki, Ocalić wiarę, wolność, króla z królów zrobić, Wyniszczyć wiarołomców, prawowiernych zdobić;

Zastanów swe impeta w teraźniejszej sprawie!

Kuźma króla wyrywa w pośrodku Warszawy, Wpośród wojska licznego czyni zgiełk i wrzawy; Kuźma kmiotek, poddany gorliwością zdjęty,

Tyran poprowadzony, strzelany i cięty,

Bity mocno, szarpany i z szat obnażony,

$W$ gęste knieje na pastwę krukom wprowadzony;

Drży Warszawa, lęka się Saldern swej roboty,

Trwożą się zauszniczki, Moskwa puszcza groty.

Po ulicach ze strachu tłuszcza sobą trwoży,

Zbestwionej zgrajej wtenczas lud się na nich sroży,

Wybranych katolików raduja się serca,

Że pozbywa tyrana krwi polskiej morderca.

Ale tu przykre echo, że Stanisław żyje,

Z Kuźmą, swoim zabójcą, w młynku wodę pije,

Ten zdrajca Kuźma, Kaim, chce zabijać Abla,

Czego polska nie chciała podła czynić szabla.

Znać, że nie wart był więcej ten husyta srogi,

By klejnot krwi szlacheckiej mieszal się $w$ to drogi,

Nie wart i ten pardonu, owszem, szubienicy;

Ten tyran, ten zabójca, więc nie masz różnicy.

Jednak co czyni dumny wiersz pasterskiej szkoły?

Okryśla paskwilami zbiór zbawienny pczoły,

Słodki owoc zaprawia trucizną i błędem,

60 Dziczego smoka kształtem, Iwim z sarny zapędem.

Przyttumić wybór cnoty chcą dokończyć piorem,

Czego nie mogli zdrajcy wykrętów swych zbiorem

Dokonać przez czas długi, on swoim rozumem

Pomoże, tak jak psi trup zasypany rumem.

Głupi rozumie, chcesz to zegnać na lud święty,

Byś sam został szalony i z Polski wypchnięty!

Spominasz wiarę, zbrodnie, Boskie tajemnice,

Nie umiesz jednak czynić dokładnej różnice.

Mieszasz razem Alkoran z Boskim pomazańcem,

Znać, żeś Moskal wyrodek lub jesteś mieszańcem,

Tłumisz dzielność wybranych, sprawiedliwe męstwo,

Chcesz w słowach, nie w istocie przypisać zwycięstwo.

Mniemasz być już szkaradą, szalonym zapałem

Gorliwość, która wiary katolickiej wałem,

75 Okryślasz burze świata i pożar nietrwały, 
Chyba dla tych, jakeś sam zdrajca, zdrajców stały.

Straszysz pany, książęta polskie i Europy -

Pewnie, że niech wstępują w przodków swoich stopy,

Niech ich równie przenika ten odgłos straszliwy:

„Ginie wolność i wiara, kraj jest nieszczęśliwy!"

Zasiągasz tajemnice Boskich rządów wiele,

Sam nie wiesz, co się dzieje, mówię ci to śmiele,

Liczysz królów, upewniasz zatym narodowi,

Wystawiasz na cel cacko prostemu gminowi.

Że dobry i cnotliwy, czy nie z twych przykładów

Sprowadził Moskwę Polszcze i innych sąsiadów?

Ukazujesz kroniki, szukasz w perspektywie,

Sternikiem chcesz się robić - pewnie w dziurę chciwie!

Plyń, jak chcesz, bez zawodu i nie bój się fali,

Nie waż się, boś dość letki, więc nie szukaj szali,

Wzroku w tym nie odmieniasz, styruj tylko śmiele,

Choć wraz z królem, przynajmniej nie w naszym Kościele.

Wspominasz trwoge króla, jędze i sztandary,

Szkoda, że cię nie wzięły wprzód Plutona mary,

Żebyś był w tej rozpaczy z krzykiem, gminem, szturmem,

Z złą czeladzią i ojcem przepadł w piekło hurmem,

Bo jak widzę, że serce masz $z$ twardej opoki,

Pokarm był jad tygrysa, pierś - tatarskie smoki,

Która cię wykarmila, gdy żólć w słodycz mienisz,

Nieszczęście sądząc szczęściem zbiór tak mało cenisz

Wybornego w Ojczyźnie ludu Lecha w gronie

Zlym jadem napuszczając zarażasz ich skronie.

Dobrze piszesz, że królów Bóg stawia na tronie,

Lecz od Tegoź faraon król w dnie morskim tonie.

105 Że twój żyje, nie ciesz się, morzaś nie przepłynął,

Król słaby, tyś niemocny, impet wasz już zginął,

Utwierdzasz go na tronie chyba swoim pismem,

Nie szarp się, bo zginiecie z takim katechismem.

Prawda, że był w nieszczęściu zdrajcy Kuźmy chłopa,

110 Będzie miała co pisać w czasie Europa,

Lecz się temu nie dziwuj, że go Bóg ocala,

Nieprędko szturm machinę z gruntu swego zwala.

Miękczy Bóg zbójcy serce skrzepłe twardym glazem,

By ziścil sprawiedliwość na was wszystkich razem,

115 Daremny przeto twój zbiór, plonne wszystkich usta,

Nie będzie Stanisława na tronie Augusta.

Dźwigaj więc, cny Polaku, śmiele ciężar srogi,

Oswobodzisz Ojczyznę, wiarę, klejnot drogi,

Z wolnością wyratujesz przodków twoich kształtem,

120 Lutrów precz powypędzasz, kalwinów ryczałtem.

Nie stanie $i$ adherent, widząc słabe siły, 
Nie dosiedzi, uciecze bojąc się mogiły,

Ty wtenczas tryumfalnie zostaniesz w swej chlubie,

Wydźwigniesz wiarę, wolność, krwawożyrców w zgubie.

Zostawisz swym potomkom nieśmiertelną sławę,

Biskupów oswobodzisz, utrzymasz buławę,

Kościół różą zakwitnie, krew w purpurę twoja

Zamieni się, gdy wiernych zostanie ostoja.

Ciesz się, miła Ojczyzno, że masz takie syny,

130 Którzy na twych wyrodków zasadzili miny,

Niech idą na powietrze, niewarci tej roli,

Której plon sprawiedliwy drży, jęczy w niewoli.

Wyssali krew niewinną te zgniłe upiory

$Z$ prawowiernych Polaków, chcąc doczekać pory,

Zatracić wiarę, wolność, szlachtę wziąść w poddaństwo,

Świątnice porujnować, zgubić całe państwo.

- Bądź stały, synu mily, wspomniej afekt matki,

Zachęcaj twoich braci, wszak to moje dziatki,

Brońcie żwawie, bym w pazur nie wpadła Iwów srogich,

140 Nie straciła swobód mych i klejnotów drogich.

Ten, który mnie odstąpił, sam niedługo zginie,

Nieczujność i lenistwo zostanie w perzynie,

Przetrzej więc błonkę z oczu, mężny bohaterze,

Nie żaluj krwi wylania, łącz się z nimi szczerze,

Oddaj $w$ azard majątki, życie zaś $w$ ofiarę

Całopalną poświęcaj, a utrzymasz wiarę

(Dalej półtorej linijki nieczytelnego tekstu; tu koniec kodeksu rękopiśmiennego.)

2. Odpis na wiersze ojca Naruszewicza, profesora Kadetów $w$ poetyce, sacratissimi ordinis Soc. lesu, przez pewnego dysydenta Wielkiego Księstwa Litewskiego

Rps PTPN 399 k. 5-6 v.

Przestań szczekać, podchlebco, stul pysk rozpuszczony,

Kogo zowiesz szalonym? Sam jesteś szalony!

Patrz, że twoja regula i zakonne prawa

Nie każą się tam wdawać, gdzie kłótnia i wrzawa,

5 Ty zaś swoje ustawy i prawa zakonu

Winien jesteś zachować aż do życia zgonu,

A nie w sprawy wdając się przeciwne stanowi,

Klęskę sobie przynosisz oraz zakonowi.

$\mathrm{Na}$ was patrzy świat cały i wam to przyznaje, 
10 Że $\mathrm{z}$ was kłótnie największe i burza powstaje.

Czego doznały Franki, Hiszpan, Luzytany,

$\mathrm{Na}$ to się skarżą naszej Ojczyzny trzy stany.

Bez względu na to, z krajów że ich wypędzają,

Pisma i zdania onych jawnie potępiają

15 Wszędy za ich obłudne mowy, rady, zdania,

Chytre podejścia, zdrady, sztuczne oszukania.

Dziś widziem, jak królowi nisko się kłaniają,

Wiersze piszą i kształtną cześć mu wyrządzają.

Widzieć będziem, jak się ta odmieni figura,

20 Jako odmienna będzie w tych księżach postura;

Tak się będą przymilać królowi nowemu,

Tak winszować i radość oświadczać innemu,

iz się chytrość, obłuda na jawie wynurzy,

Która w gorliwych synach Ojczyzny krew burzy.

25 Za bezbożne bezbożnych dziej niniejszych chwały

Niech wie, że cierpieć będzie wierszopisz zuchwały.

Jaka sie prawda, prosze, w tych wierszach wydaje?

Wstyd pisać, że ksiądz, kapłan, szalbierzem się staje.

Gdzie ten senat, pisarzu, głowy pozbawiony,

30 Gdzie rycerstwo, gdzie kmiotek żalem rozrzewniony,

Gdzie głowa, co porządek dobry utrzymuje,

Gdzie, ojciec, co w uciskach i w nędzach ratuje?

Gdy jest - jakby nie było - król jaki bez mocy,

Szukający dla siebie moskiewskiej pomocy

35 I pod jej rządy wolną Ojczyznę poddaje,

Sam się oraz bez wstydu niewolnikiem staje,

Sam Ojczyźnie z Moskalem niespokojność czyni,

A niebacznie najmilszych jej obrońców wini.

Czy oni nieprzyjaciół w kraj nasz wprowadzaja,

40 Czy bronią i orężem silnie wypędzają?

Oni dla swej Ojczyzny lat siedem wojują,

Dobra, życie i zdrowie mężnie hazardują,

I oniż, że z Warszawy Stanislawa wzięli,

Taką hańbę, niesławę stąd zaciągnąc mieli?

45 Mylisz się, który sądzisz, iż źle uczynili,

Że szturmem na waszego króla uderzyli.

To dzieło mędrsze glowy za was ułożyli

I wcześnie dla przestrogi wszystkim ogłosili,

Że tego, dla którego kraj nasz cały ginie,

50 Prędzej-li czy-li później śmierć pewnie nie minie.

Powszechna bowiem pisząc uczy nas kronika

Niezdatnego do styru odrzucić styrnika,

I łódź łatać do niego należy samego,

Jeśli tego nie umie, odmienić innego.

55 Tu kraj cały pod jarzmem niewolniczym stęka, 
Tu patrzym na rabunki, jako sroga ręka, Którą Polacy w swoim państwie wytrzymują,

Że wolności praw, wiary jak mogą ratują.

Tu pospólstwo zgłodniałe, kmiotek wycieńczony,

60 Tu pan, szlachcic i każdy w nędzy zubożony,

Tu o swój wziątek wola czeladka troskliwa,

Woła wszelka rozumna, wszelka dusza żywa.

Panie, zemściej się nad tym, czyja to jest wina!

Król tego, nie kto inny jest pierwsza przyczyna.

65 Tego klnie senat, gwałtem Moskwy znieważony,

KInie więzień i lud wszystek żalem rozrzewniony,

Ci wszyscy, co się w cudzych granicach tulaja,

O jaką, proszę, pomstę do Boga wołają,

Że musieli wyjechać z ojczystego państwa

70 Bojąc się okrutnego Moskalów tyraństwa?

$O$, jaką radość $w$ sercach strapionych wznieciła,

Gdy wieść wszędy o wzięciu króla rozgłosiła!

Pewnie wszyscy w skrytości Bogu dziękowali,

Że zlego z swego kraju rządce postradali.

75 Cieszyli się już wszyscy, że pokój nastąpi,

Że Moskal nieprzyjazny wstecz z granic ustąpi,

Lecz gdy przeciwna szczęściu chwila nastąpiła,

Ta króla przywracając wszystkich zasmuciła.

Znowu płakać, narzekać, jęczeć zaczynają,

80 Że nędza, okrucieństwo z królem powracają.

Wiedząc, że lud płaczący po mieście się snuje,

Mniemasz, pisarzu, króla że twego żałuje,

Bez względu, że pospólstwo nędzą uciśnione

Tym rzewniej płakać musi powrotem strapione.

85 Nie radość, ale smutek był przyczyną płaczu,

Zbłądziłeś w swym mniemaniu, mój mądry tlumaczu,

Zbłądziłeś, żeś tych nazwał ludzi zabójcami,

Którzy są prawdziwymi kraju obrońcami,

A że wzięli z Warszawy mniemanego krola,

90 W tych glów mędrszych i pewnie nastąpiła wola;

Którzy widząc $w$ tym królu obraz malowany

Nie chcą, z wstydem krajowym by był królem zwany,

Nie chcą, by z nim w Ojczyźnie prosty Moskal rządził -

Tę ligę rozłączając żaden nie pobłądził.

95 Godny rotmistrz Kosiński, że tego dokazał,

$\mathrm{Na}$ co się z wielkich mężów ledwie kto odważał.

Zjednal sobie $w$ narodzie miłość i pochwałę,

Zjednał w krajach postronnych przez wiek sławę stałę.

Kto się trwogą odwodzi, kto życia żałuje,

100 Kosiński z tą się wszystką mężnie azarduje,

Sądząc z sobą: niech jeden król Polak krwią płynie, 
A niechaj z rąk Moskala kraj cały nie ginie.

Wielkie twe jest, rycerzu, dzieło wielkiej wagi,

Żeś dał dowód Ojczyźnie męstwa i odwagi,

105 Ta zaś twoja niewola i twe umartwienia

Jest do końca pobudką klęsek przyspieszenia.

Niech ci ludzie podchlebni bezbożność poznają,

Niech się być wiernym synem ojczyzny nie znają,

Niech buntownikiem, zbójcą, niech ich hersztem zowią,

110 Niech, co im rozum każe zaślepiony, mowią,

Oni to czynia, jedni złotem przekupieni,

Na godność drudzy z nędzy nagle wyniesieni,

Którzy o dobro kraju powszechne mniej dbają,

Lecz w swoich tylko szczęścia osobach szukają.

115 Na jakiej, patrz, godności, choć na czas, stanęli,

Którzy żadnej nadziei z nich przedtym nie mieli:

Aleksandrowicz, Karaś, Tyzenhauz, Branicki,

Młodziejowski, Ogrodzki, Ronikier, Borch, Kicki,

Kossakowski sekretarz, Gurowski, Szydłowski,

120 Niesiałowski, Burzyński, Turski, Ożarowski!

lakiego zdania, rady ich godne szacunku,

‘azdy pozna z osoby, pozna i z gatunku,

Oni przedać Ojczyznę i zaprzeć się wiary

Gotowi za królewskie sobie dane dary,

125 A swe zdrady płaszczykiem cnoty ukrywają,

O występek obrońców państwa obwiniają,

A chcą tego, by wszystkich kształtnie oszukali,

A ich wykrętów chytrych wszyscy nie poznali.

Kraj cały na to patrząc i postronne państwa,

130 A widząc nieprzyjaciół okrutne tyraństwa,

Widząc, że całym państwem brzydki Moskal rządzi,

Słusznie, że „Króla nie masz!” ogłasza i sądzi,

Słusznie naród na tego swą rękę podnosi,

Który malowanego króla imię nosi

135 I najmniej ten przypadek innych królów tyka,

Od którego równości król każdy unika.

Każdy takim być królem i rządcą się wstydzi,

Z którego się lud śmieje i Europa szydzi,

Każdy w swym państwie królem i każdy monarcha

140 Sam rządzi w swych granicach, a nie Moskal parcha.

Bardziej się wszyscy śmieją z waszego pisania,

$\mathrm{Z}$ waszego złośliwego $\mathrm{w}$ mowach rozszerzania,

Śmieją się z pompy wjazdu, któryście czynili,

Niezadługo skończy się to wszystko po chwili,

145 Skończy się wasza godność, radni, ministrowie,

Złych skutków, zuchwałości najpierwsi hersztowie.

Co czynicie z Kosińskim, wy sami nie znacie, 
Jak tym więźniem swój cały naród rozjątrzacie.

Cokolwiek wy królowi swojemu radzicie,

150 Ciężko na waszych radząc rozumem błądzicie, Rozumiecie, że wszyscy wam to pochwalają,

Którzy się nad królewską klęską użalają.

Kanclerz i podkanclerze, litewscy, koronni,

Drwią z was tak wszyscy swoi, jako i postronni.

Próżna twoja troskliwość, mój marszałku wielki,

(.

Co ma pewnie nastąpić, to nastąpić musi,

Nie obronią zebrani was ulani kusi,

Życzę ludzi nie lapać ani ich mordować,

Lecz w powinnych obrębach swój urząd sprawować.

160

Próżne wasze pogróżki, próżne są przechwaly,

Oszuka się wasz rozum miałki i niestaly.

3. Od narodu do poety ubolewającego nad przypadkiem intruza w Warszawie doświadczonym roku 1771 die 3 listopada

Rps PTPN 816 s. $145-148$

Podchlebstwo tak jest szkodliwe obyczajom, jak arszenik życiu ludzkiemu. Księża, was najwięcej prawda interesuje, których glosowi jest powierzona Ewangelija. Duchowieństwo, slowa wasze kaznodziejskie nie powinny być kwiatem, co pachnie, ale nożem, co rżnie. Prałaci, was cucić powinno namiestnictwo Chrystusowe do nauki, aby pomazaniec Boży był przykładny, a lud pod nim obyczajny. Słowem - gdzie panuje cnota, tam truchleją i martwieć muszą występki.

Regis ad exemplum totus componitur orbis.

Dzień jasny pokazuje z polskimi obroty,

Że tyle jest król królem, ile w nim jest cnoty,

I gdybyśmy pamięcią królów w grobie strzęśli,

Więcej $z$ ich prochów sławy niż dźwięków z tej gęśli.

5 Dzień jasny, co się tylko laskawy nadarza,

Inszego nie masz podług Augusta cesarza.

Dzień, którym dysponuje złość czy-li pokusa,

Ten niewart i jednego promienia Febusa,

Przeto noc, przeto ciemno, przeto sto pochodni

Swiecić powinno, chcąc się pilnować od zbrodni,

A kto z czystym sumieniem i z tą myślą kroczy,

Trafi gdzie mu potrzeba zamrużywszy oczy. 
Jednak nie ma tu chwały rozbójnicza droga,

Bo eksces jest bezprawiem, a grzech krzywdą Boga,

Chociaż i Bóg przepuszcza podług zasług miary

I zbójcy być złośliwszym, kto jest godzien kary.

Przeto każdy takowy nie jest $z$ tego tłumu,

Kiedy się sprawiedliwość poczęła z rozumu,

Kędy Mars patrzy z oczu, a Saturnus z czoła,

Męstwo z piersi, któremu północ nie wydoła,

Kędy cnota dowodzi nie ustając, aże

Wszystko wytchnie i światu dowodnie pokaże.

Więc zbójeckiej imprezie, która cnotą gardzi,

Próżno grać i na dudzie, na gęśli tym bardziéj.

25 Lecz gdy coraz, poeto, zaczynasz tym smutniéj,

Domyślam się, że swemu panu grasz na lutni.

Zwyczajnie dla rozrywki, jak w przypadku którym

Znając nuty, będę ci dopomagał wtórém:

Prawny król - i prawności pamiętna przyczyna,

Wprzód ukaz Kiejzerlinga, a potym Repnina;

Dobry król - i myśl dobra, bo chętnie pozwala

Pognębiwszy Polaków wszystko dla Moskala;

Mężny król - i nie masz go w okręgu Europy,

Aby tak śmiało patrzył na krwi swej potopy;

Hojny król - nad naturę swego majestatu,

Bo pozwolił wziąść z posłem trzech mężów z senatu;

Mocny król - i nie pomną nigdy lata stare,

Aby który miał łamać wraz wolność i wiarę;

Mądry król - i co większa, dowcipny się zdawa,

40 Bo sobie wynicował kardynalne prawa;

Szczodry król - w dystrybucie, nad dawne zwyczaje

Ten podłym tysiącami szlachectwo nadaje;

Modest król - i jak mówią, w panowaniu całym

Bez braku po bratersku żyje chlebem białym;

Przykladny król - i ta jest w nim pobożność szczera:

Oltarz by się nie złamal, wota z niego zbiera;

Polak król - z jagiellońskiej krwie, znany z dowodu:

On z Moskalem, z nim Moskal są przeciw narodu.

Owoż, król gdy jest z takich postępków i prawa,

Co za dziw, że ma zbójców wśród siebie Warszawa?

Gdy zły przyklad z monarchy, więc instrument na co?

Tam bez nasienia wszystko rodzi się ladaco.

A zatym, mój poeto od lutni czy gęśli,

Kiedyśmy po szczeremu te nuty przetrzęśli,

55 Sfolgujmy instrumentom czy-li sobie raczej,

Są metrowie $w$ narodzie, zagrają inaczej.

Sfolgujmy, jako mówię, ile już po probie,

Jednakowo przyczynę mam mówić o tobie: 
Żeś K. wreście napisał, ciekawość mnie ściska,

60

Nie wiem, czy na znak wiersza, czy na znak nazwiska?

4. Mateusz Czarnek

Rps Bibl. Czart. 781 s. $347-350$

Najjaśniejszy Królu, Panie mój miłościwy!

Królu! Twoje do swoich cudowne przybycie

Wiernym tobie poddanym przywróciło życie,

Którzy i zadziwieni, i razem weseli

Czy się cieszyć, czy plakać mają, nie wiedzieli.

5 Ta jest twego starania o ludziach nadgroda,

Ty ludziom, Bóg ci sposób życia za nich poda,

A kiedy nieprzebytą zasłania cię tarczą,

I tysiące złośliwych szkodzić nie wystarczą.

Już uprząta przeszkody wszelkie ręką własną,

10 Nieprzyjaciele twoi oczywiście gasną,

Ani nie byto nigdy pewnie w ludzkiej mocy,

Ażeby można Boskiej oprzeć się pomocy.

Przekonani jesteśmy, żeś cudownie panem,

Przywrócony sposobem nigdy nie słyszanem,

Wieść już skrzydła opuszcza, lękają się dzieje,

Nadzieja uprzedzona, myśl życzyć się chwieje.

Stąd okrzyki, stąd radość razem z łzami stawa,

Stąd twoimi chwałami zabrzmiała Warszawa.

Wszędzie odgłos słyszany, ale jednak, Panie,

Milczeć, gdzie wszystko woła, występkiem się stanie.

Wieczorna gwiazdo, czy-li na okrągłym niebie

Gore ogień nad ziemią niemilszy nad ciebie,

Która od dzieci ojca wydzierasz na męki

I syna z lona matki, a dajesz do ręki

25 Ludziom niewzruszonego serca niesłychanie?

Czy dziki gorzej czyni, gdy miasta dostanie?

Nie prędzej wieść stousta glosi traf tak srogi,

Że skargi, placze, troski wpadły w miasta progi,

Frasunki i wzdychania $z$ żalami $w$ tej porze

30 Niezliczoną gromadą osiadły na dworze.

Tak kiedy sroga żolna nad ul się zakradnie

I chwyta biednym pszczolkom tego, który władnie,

Niebogi w tym nieszczęściu lecą w wszystkie strony

Myśląc, że brzękiem będzie lub żądlem zbroniony,

35 A tymczasem nie wiedząc, gdzie się on podzieje, Jedna się żegna z ulem, druga z strachu mdleje - 
Tak wierni twoi, królu laskawy, poddani

Upadli twym upadem i byli stroskani.

Krzyczeli zadumieni, utraciwszy ciebie,

I były wysluchane smutne głosy w niebie:

„Jeśli karzesz niecnoty, Królu światowłady,

Karz nas samych, bo żaden z nas nie jest bez wady;

Lecz ma-li odpowiadać za nasze występki

Ten, którego niewinne przed światem postępki?

Słodka sprawiedliwości, zmiękcz się naszym żalem!

Życiem naszego pana i my się ocalem!

Spojrzyj na lud spłakany, na lękliwe matki

I już wyglądające śmierci slabe dziatki!

Czy-li kiedy to miasto gorzej ukrzywdzone

50 Mogło być w nieszczęśliwym smutku pogrzebione?

I czy-li pamiętają brzegi sławnej rzeki,

Żeby przykład podobny mialy dawne wieki?

Pryjamus, król łagodny, ginie w miasta tonie,

Które ledwie w tej krwawej bitwie nie utonie -

55 Sroższy nasz los: on ginie na swych trupów stosie,

Miasto się grzebie z królem w wiekopomnym losie,

My utracili króla, i jeszcze żyjemy!

Albo niech się powróci, albo niech giniemy!

Brzydkiej tylko niezgody okropne zwyczaje,

Która się żadnym prośbom ubłagać nie daje,

Która w nielitość mając obleczone zbroje

Same lubi pożary, krwopłynne zaboje;

Miłe jej wywrócone widzieć miasta, grody,

I ludzi zdartych z życia przyjemnej swobody.

65 Jej to strach i okropna mara słudzy wierni,

Mara, co trzyma z żółcią czarę, berło z cierni.

Czy będziesz śmieć słuszności imię teraz nosić,

Żeby w zlości niewinność ogniem, mieczem znosić?"

Ale, królu, jak ludu była chęć prawdziwa,

70 Tak prędzej wysłuchała prośby Ręka mściwa.

Wróciłeś się nam, panie, przy zdrowiu niewinny,

Uspokoiłeś w wszystkich strach sześciogodzinny,

Który przeto nam lekszą zrobił przykrą karę,

Żeś powrócił cudownie, żeś przybył nad wiarę.

Lecz nieco zapomniawszy o srogim hałasie,

Weselszych zażywajmy myśli w takim czasie.

Bijcie $w$ bębny $z$ trąbami, ale nie $w$ te glosy,

$Z$ jakich w szalonym Marsie najeżą się włosy,

Gdy na wozie, serdakiem żelaznym odziany

80 Między wojska stalową ręką sieje rany;

Uderzcie takim wzorem, jako złotorucha

Przyjaźń, nieprzyjaciótka bojom, rada słucha. 
Już się dasz uspokoić, Rządzco władogromy!

Tobie cały występek najlepiej świadomy,

85 Zdrada w kształcie roztropnej mądrości dziś stawa, I w pozorze dzielnego serca - wzgarda prawa.

Prawda, że zawsze prawa były kolca twarde;

Kiedy nimi przycisną, zniżą się i harde, Ale obywatele nimi ocalone,

90 Nimi z upadłych rumów miasta wyniesione.

Śmieliśmy wprzód uzbroić niebo gniewem srogim, Gardząc Jego nadanym państwu darem drogim, Jeszcze obracać groty nad ludzkie nadzieje Nie na nieprzyjaciela, lecz na dobrodzieje!

95 Ale pamiętać trzeba, że wzburzają pole Rządzcy państw, lecz bogowie uzbrajają krole. Bóg to sam, który swój miecz podnosi surowy, Ostatniej zemsty zażyć chcąc na nasze głowy, Kiedy się nam w ostatku tak rozum przewroci,

100 Że chcemy stargać Jego granice dobroci. Lecz, Boże, niech żal ludu szczery i głęboki Zawiesi jeszcze Twoje niezłomne wyroki! Wiem, że dość panu będzie, iż złe wiekopomne Wieczność mu wystawiło na czasy potomne,

105 Wyrządzonych krzywd sobie zapomni laskawie I pomoże ludowi swojemu w złej sprawie. Ja w wielkim zadziwieniu tylko milczeć muszę, Zważając w sobie pana wielkomyślną duszę.

5. Oda z okazyi ocalenia drogiego życia Najjaśniejszego Króla Jegomości Stanisława Augusta

Rps Bibl. Czart. 781 s. 371-375

Okropnym Faetona król Cygnus przypadkiem, Jako jest tego wiernym historyja świadkiem,

Tak mocno był wzruszony, że człowiekiem zostać

Nie chcąc więcej, w łabędzią przemienił się postać.

5 Amfinomea, matka sławnego Jazona,

Długim niewidzeniem się z synem umartwiona, Uspokoić się $w$ żalach nie mogła inaczéj,

$A \dot{z} w$ sercu utopiła puinał $z$ rozpaczy.

Pierwszemu przyjaźń, drugiej afekt był powodem

10 Do okazania czułych skutków tym dowodem,

Przywiązanie w nich znać się dało tak obficie, 
Że drogie na ofiarę poświęcili życie.

Dziś, miłościwy królu, kogo z gruntu duszy

Twój tak straszny przypadek nie dotknie, nie wzruszy?

15 Tego chyba, kogo nic wcale nie dosięga, Obowiązek poddaństwa, wierności przysięga.

Lud przez ciebie rządzony w kraju okolicy

Ten przeraził trefunek, część zaś w tej stolicy

Smutne czyniąc świadectwo tak okropnej scenie

20 Żal czuje przez tak długie ciebie niewidzenie.

Stan duchowny, stan świecki, mieszkaniec, przychodzień,

Najgorętsze do Boga modły wnosi co dzień,

Aby mu jak najprędzej wolność była dana

Oglądać w dobrym zdrowiu łaskawego pana.

25 Ta Ojczyzna, która cię wprzód na własnym tonie

Wychowawszy, monarchą wyniosła na trónie,

Otaczające zewsząd tym słodzi strapienie,

Ze widzi kochanego ojca przywrócenie.

Wielbi dziś Opatrzności opiekę łaskawą

30 Nad podźwignioną z strasznych nawałności nawą,

Którą pogrążyć kilku wyroków swywola

Chciała, styr wyrywając z rąk mądrego krola.

Naród, który monarchom bywał zawsze wierny,

Zupełną stąd pociechą dzieli żal niezmierny,

35 lż gdy ten cnotę jego postępek obrazit,

Za sprawą niebios jednak $z$ gruntu jej nie skaził.

Weseli się, iż w królu tak dobrym obrona

I powszechna szczęśliwość jest mu przywrócona,

Kiedy, znosząc zniewagę, cierpiąc rany, blizny,

40 Mówi: Wszystko to wyjdzie na dobro Ojczyzny.

Jeśli kto nienawisny znalazł się w narodzie,

Uspokoić się winien w zawziętej niezgodzie,

Przyświadczyć jednomyślne monarchy obranie,

Gdy Bóg sam cudem stwierdził jego panowanie.

45 Niech tylko taki zacność króla pozna z bliska,

A prywatnych niechęci odstąpi igrzyska,

Gwaltowne wewnętrznego zamieszania burze

Nie monarsze - dzisiejszej przyzna koniekturze.

Religija, wspaniałość duszy, stałość zdania,

50 Rozum, dobroć, roztropna sposobność władania,

Darem słodkiej wymowy napełnione usta -

Prawdziwe Stanisława porterty Augusta. 
Zasłużonym nadgroda, wiernym lask szafunek,

W przypadkach i nieszczęściu poddanych ratunek,

Przez uprzedzanie zasług pobudka do cnoty -

Te są w nim tron zdobiące wrodzone przymioty.

W takowym o monarsze będąc przeświadczeniu, Jakże można w niesłusznym zostać uprzedzeniu, Jak, mówię, można z cnotą występek pogodzić,

60 Żeby dobry król własnej ojczyźnie chciał szkodzić?

Próżne tego gatunku myśli i przesądy,

Czyż bowiem znane komu woli Boskiej rządy?

Może za swe przestępstwa naród w jarzmie stęka,

Którym go dziś wszechmocna przycisnęła ręka?

65 Concordia u Rzymian bożyszczem wielbiona

I wspaniałym wśród miasta kościołem uczczona

$Z$ tej miary szanowana byla za boginią,

Że słodkiego pokoju oznacza mistrzynią.

Ty, którą wszystkie stoją i kwitną narody,

70 Brak nam jednomyślności i domowej zgody,

Niesforność zdań, zawzięte myśli rozdwojenie

Wprowadziły dzisiejsze w kraj uciemiężenie.

Czas by już w niebezpiecznych wstrzymać się zapędach,

Nie zasadzać się dłużej na prywatnych względach,

Rządzić się staropolską cnotą, wzorem przodków

Chwycić się użytecznych dla Ojczyzny środków.

Boże, tą mocą, którą stworzonej machiny

Świata obracają się najmniejsze sprężyny,

Przywróć miłą spokojność, zlituj się nad ludem,

Gdy przywrócenie króla zna być twoim cudem!

6. Do Najjaśniejszego Pana dobry obywatel

Rps Bibl. Czart. 781 s. 385-389

Livor licet dolensque verberibus dolus Ad furta sese et proelia accingat nova, Virtus sed ipsa cedere aut vinci nequit, Et quo magis tractatur, effulget magis.

Bencius

Niech zazdrość, zdrada jakie chce bierze przemiany

Idąc w otwarte pole na bój, abo z skrytej

Napastując zasadzki, zawżdy pokonany

Nieprzyjaciel wygranej nabawi sowitej, 
Nie umie, rzekł ktoś, cnota inak zwodzić wojny,

Zawżdy plac bierze, zawżdy same przeciwniki,

Co jej zawiśni darom skarb pustoszą hojny,

10 Silną prawicą wtrąca między niewolniki,

Wedle zasług miary

Odmierzając kary.

A lubo bywa czasem, że zasępi chmura Złote słońce na niebie, śląc okropne cienie,

15 Nigdy jednak ta postać na wszystkim ponura

Dlugo nie trwa, ustąpić precz musi zaćmienie,

A Feb z dżdżystej toni

Dzień zaczęty goni,

Niosąc pogodę jasną ziemskiemu stworzeniu

20 I lustr swój stęsknionemu natężając oku,

A niźli był widziany kiedy w przyrodzeniu

Przyjemniejszy z grubego wyszedłszy obłoku;

Większej tak Bóg imię

Twe poda estymie,

25 Wielki monarcho, wiecznym w ksieggach niezapomnych

Palcem wyrywszy wszystkie trudy twe podjęte,

I z srogich jędz tryumfy ku dziwu potomnych

Kładąc między przewagi bohatyrów święte, Kiedyś zwalczył mocy

30 Tak okropnej nocy.

Potomnych... bo ta dola opłakanych ludzi,

Że nigdy przytomnego szczęścia nie poznają,

I tylko towiąc pozór sam, który ich łudzi,

Istote pozad wiekom idącym oddają,

Zawżdy bez nagrody

Podjętej w tym szkody.

Tak w powszechnym wielbieniu przodek twój Jan Trzeci

Prawdziwym królem, ojcem od wszystkich nazwany,

To: Piast, to: to wojownik! - i możni, i kmieci

Dziś mówią; azaż tymże, gdy żył, był uznany?

Niech o tym powiedzą,

Którzy dzieje wiedzą.

Tak on Stefan Batory, tak... ale, ach, wstydzie! Tak wszyscy, wiele było monarchów na tronie

Najżyczliwszych Polakom, w największej ohydzie

U Polaków przetrwali. Aż teraz po zgonie 
Gdy oni zamknęli

Oczy, ci przejrzeli.

Potomnych... bo się ręczyć trudno o te lata,

50 Których cnocie naprzeciw ogromne ołtarze

Świętokradzką prawicą spikniona prywata

Zbudowawszy, najświętsze k'woli swej ofiarze

Tajemnice bierze

Najwłaściwsze wierze.

55 Tam dopiero z zrzenice otarłszy mrok gruby

Baczniejsi ślepych ojców obaczą synowie,

Że noc, której najblizsi byli ci do zguby

Pozornymi preteksty zmamieni przodkowie,

Szła nie z słońca winy,

60 Lecz z samych przyczyny.

Abo jaśniej: że sprawy drogie twoje, Panie,

Nigdy nie podlegały czarnemu zaćmieniu,

Ale tylko obłokiem że zasute na nie

Patrzyły oczy, ciemne zdały się widzeniu

Ludu, który sądzi

Po wierzchu, i błądzi.

Tam z uwikłanych imprez kłąb chytrze uwity

$\mathrm{Na}$ osnowę rozwiedzion, ukaże na oko

Koniec swój tak subtelnie dopiero ukryty,

70 Niby pod motowidłem zawarty głęboko,

Ze nie zna go wiele

Pomocników w dziele.

Ukaże i zawstydzi sprawcę złej roboty,

Nie więcej złotej przędzą wolności i wiary

75 Mamiąc, świętej niewinne obrońce prostoty,

Ale godne zasługom odbierając kary

Stargany mocnymi,

Królu, czyny twymi.

Nie powiedzą już więcej, za co to miecz srogi,

80 Za co żołnierz swawolny tak się rozpościera

W oczach pana? Czemu lud tam i ówdzie mnogi

Za miły pokój wrzawę wojenną obiera,

A wyszedłszy w pole

Placze na swe dole?

85 Bo to u nich nie będzie bajką i pozorem,

Żeś do mdłości szkodliwym zastawiał się radom,

Żeś z uszczerbkiem powagi idącym oporem

Ojcowskie dawał śrzodki ku zgodzie, układom, 
$90 \quad$ Myląc nieraz płazą

Lecz tylko, że tam trudno było leczyć ranę,

Gdzie chory najpewniejszych lekarstw nie przyjmowat,

Trudno tam od przepaści zwrócić rozbieżane,

Kędy cugl od niekarnych zrzucon nie hamował,

95 Acz na sprawcy rzeczy

Tej, nie zeszło pieczy.

Owszem, krew twą przelaną zbrodni na ofiarę Jako świątość polskiego wielbić będą tronu, Kładąc ciebie obrońcę między one stare

100 Pierwej Polskiej, a teraz mieszkańce Syjonu, Boś dla cnoty z niemi

Ucierpiał na ziemi.

A przetoż utul żal twój, królu dobrotliwy, Obwiń ranę pamięcią wieków przyszłych chwały,

105 A spojrzawszy na radość, którą kraj życzliwy

Odnosi zdrowia twego, uznaj, że niemały

I dziś poczet cnoty

Zna króla bez noty.

7. Tekst z przyczyny przypadku przez Jego Królewską Mość doświadczonego

Rps Bibl. Czart. 781 s. 393

Uzbrój się orężem, Kto się zowiesz mężem, Zniewagi twego pomścij się pana!

Stawaj ku obronie Zelżonej koronie,

Zważ, jaka krzywda jest jej zadana!

5

Ludzi nierozumnych, Złość burzliwa, Niegodziwa

Niechaj zostanie przez cię skarana.

Któreż świata strony Jak liczne zgraje zbójców czyniły?

10 A sceny tragiczne, Okropną śmiercią panu groziły.
Szablą dana
Glowie rana

Ogromne strzelanie,

Krwi drogiej wylanie

Już, już monarchę wiodły w mogiły.

Lecz te pełne złości

Zbójeckie czynności

Że nieszkodliwe, Bóg sprawił cudem, 
By przezeń wybrany, Narodowi dany

Król nad niesfornym panowal ludem,

20 Pomyślność obfitą, Zawsze znamienitą

A mądrością $Z$ lagodnością

$W$ kraj swój chwalebnym wprowadzał trudem.

O, dzielny narodzie,

Żyjący w niezgodzie,

Słuchaj, co potym rzekł król wrócony:

25

Tym mnie krwią zbroczeniem, Rozruch domowy stanie skrócony.

Przez me blizny

Dla Ojczyzny

Przy mej niewinności

W miłej szczęśliwości

Pokój trwać będzie już niewzruszony.

Ach, przebóg, ziomkowie,

Uwierzcież tej mowie!

30

Niech się uśmierzy niezgody burza,

Niechaj was poruszy

Krzyk trwożący uszy,

Że się Ojczyzna w krwi swojej nurza!

Więc w jedności I w miłości

$Z$ królem radzić trzeba,

A tak zrządzą nieba,

Iż się to ściszy, co żwawie wzburza. 